Filol. Linguíst. Port., São Paulo, v. 17, n. 2, p. 473-493, jul./dez. 2015

http://dx.doi.org/10.11606/issn.2176-9419.v17i2p473-493

\title{
Emprego de vírgula e prosódia do Português Brasileiro: aspectos teórico-analíticos e implicações didáticas
}

The use of commas and prosody of Brazilian Portuguese: analyticaltheoretical aspects and didactic implications

\author{
Geovana Soncin* \\ Universidade Estadual Paulista, São José do Rio Preto, São Paulo, Brasil \\ Luciani Tenani** \\ Universidade Estadual Paulista, São José do Rio Preto, São Paulo, Brasil
}

\begin{abstract}
Resumo: Neste artigo, estabelecemos relaçóes entre o emprego de vírgula em textos de alunos concluintes do Ensino Fundamental e a organização prosódica do Português Brasileiro. Por meio da análise realizada, mostramos que, embora a convençáo para o uso da vírgula seja prioritariamente de base sintática, os usos encontrados apresentam regularidades prosódicas que, ao mesmo tempo, organizam a segmentação do enunciado e contribuem para a constituiçáo dos sentidos dos textos. Do ponto de vista teórico, defendemos, por um lado, que a prosódia atua como estrutura significante na escrita e, desse modo, nâo é particularidade da fala e, por outro, que os usos de vírgula, ao marcar a estruturação prosódica da língua na escrita, faz remissão, por meio de um processo simbólico, ao modo como os fenômenos prosódicos produzem sentidos em diferentes enunciados no interior de práticas de oralidade. Como desdobramento da discussão teórica, propomos que, na prática didática, enfrentar a complexidade do emprego da vírgula
\end{abstract}

\footnotetext{
Doutora em Estudos Linguísticos pela Universidade Estadual Paulista "Júlio de Mesquita Filho”. Bolsista de pós-doutorado da FAPESP no Departamento de Estudos Linguísticos e Literários do Instituto de Biociências, Letras e Ciências Exatas da Universidade Estadual Paulista "Júlio de Mesquita Filho" em São José do Rio Preto; geovanasoncin@gmail.com.

** Docente do Departamento de Estudos Linguísticos e Literários do Instituto de Biociências, Letras e Ciências Exatas da Universidade Estadual Paulista "Júlio de Mesquita Filho" em São José do Rio Preto; lutenani@ibilce.unesp.br.
} 
poderia ser mais produtivo para o ensino do que considerá-lo em sua suposta homogeneidade sintática.

Palavras-chave: Vírgula. Prosódia. Escrita. Língua portuguesa.

Abstract: In this paper, we establish relations between the uses of comma in texts written by students from the year of Middle School and the prosodic organization of Brazilian Portuguese. Even though commas usage convention is primarily syntax-based, we argue that the uses of commas in texts have prosodic regularities that, simultaneously, organize the segmentation of utterances and contribute to the constitution of sense in texts. On the one hand, we argue that prosody is a signifying structure in writing and, thus, it is not a particularity of speech. On the other hand, we defend that the uses of commas, by establishing the prosodic structure of language in writing, do reference, by a symbolic process, the way prosodic phenomena produce sense in different utterances within oral practices. As a possible application of the theoretical discussion, we propose to recognize the complexity of commas usage as a more interesting practice at school than considering its so-called syntactic homogeneity.

Keywords: Comma. Prosody. Writing. Portuguese.

\section{INTRODUÇÃO}

Neste artigo, o principal objetivo é apresentar uma análise das regularidades prosódicas subjacentes às vírgulas empregadas em textos de alunos brasileiros e, a partir dessa análise, discutir teoricamente sobre o modo como relações entre oralidade e letramento se tornam fundamentais para conceber a constituição da pontuação, em particular, e da escrita, de modo amplo. Argumentamos que considerar a relação entre oralidade e letramento é fundamental para revelar fenômenos linguísticos e processos simbólicos na escrita de jovens alunos que estão em processo de convencionalização da escrita em contexto escolar: escrita esta caracterizada preponderantemente pela flutuação entre os chamados acertos e erros, definidos com base nas convenções estabelecidas pela gramática normativa.

O chamado "erro de pontuação" decorre de uma perspectiva que vê como "influência negativa" para o ato de pontuar a relação da pontuação com características da oralidade. Nos textos analisados, os usos de vírgula (tantos os "erros" quanto os "acertos") apresentam regularidades relacionadas à dimensão prosódica da língua, ao lado de regularidades de natureza sintática, como as previstas nas regras de emprego de vírgulas. Essas regularidades prosódicas, apesar de também

Soncin G.; Tenani, L. Emprego de vírgula e prosódia do Português Brasileiro... 
caracterizar o emprego da vírgula, em geral são negligenciadas pela própria convenção que pauta o ensino em sala de aula.

No que diz respeito à flutuação entre "acertos" e "erros" observada nos textos do Ensino Fundamental (doravante, EF), a interpretamos como efeito da tensão sofrida pelo sujeito em processo de aquisiçáo da escrita: ao mesmo tempo em que precisa lidar com as imposiçôes normativas da convenção gramatical defendida e difundida pela escola e a partir da qual é avaliado, o sujeito lida também com o conhecimento linguístico de falante e escrevente da língua em diferentes práticas orais e letradas de uso da linguagem, um conhecimento historicamente constituído, portanto, e não necessariamente explicitável.

A fim de pôr em relevo essa tensão sofrida pelos escreventes, analisamos o emprego da vírgula usando como critério a organização prosódica do Português Brasileiro e atentamo-nos para os sentidos mobilizados pela relação entre vírgula e organização prosódica do texto. No entanto, não perdemos de vista a convenção e as normas que ela estabelece e, por isso, a partir da análise dos usos de vírgula, discutimos seu estatuto e tecemos consideraçóes sobre sua abordagem em sala de aula.

Para desenvolver tais reflexôes, organizamos o artigo em cinco seçôes. $\mathrm{Na}$ primeira, apresentamos os fundamentos da Fonologia Prosódica e apresentamos em que medida eles contribuem para analisar os usos de vírgula. Na segunda, descrevemos o material de análise e o modo como os textos selecionados são interpretados teórica e metodologicamente Na seção três, descrevemos as principais regularidades prosódicas encontradas nos usos de vírgula. $\mathrm{Na}$ seção quatro, discutimos como a organização prosódica subjacente ao emprego da vírgula revela a importância da consideração da oralidade para a constituição da escrita. Por fim, na última seção, contrapomos o funcionamento linguístico dos usos de vírgula e o tratamento dado a eles pela convenção que regulamenta seu emprego, a fim de discutir como esses dois modos de conceber o emprego da vírgula podem dialogar tendo em vista o ensino da escrita.

\section{USOS DE VÍRGULA E REGULARIDADES PROSÓDICAS}

Há uma tradição de estudos que defende a autonomia da escrita em relação à oralidade, concebendo, assim, a prosódia como parte externa e acessória à escrita 
(conferir a propósito, Anis, 1983) ${ }^{1}$. Neste trabalho, a abordagem da vírgula segue outra direção. Entendemos que a escrita se define pelo encontro entre o oral e o letrado, conforme propóe Corrêa (2004). Dessa perspectiva, consideramos a prosódia como uma dimensão linguística que compóe a escrita como parte constitutiva de sua heterogeneidade, característica principal da escrita segundo Corrêa (2004).

Assumir tal heterogeneidade significa, numa primeira instância, compreender o caráter não autônomo da escrita alfabética, o que implica considerar que esta se constituiu pela relação que estabelece com a linguagem articulada, em especial pela representação fonética e fonológica da língua, mesmo que essa relação seja imperfeita. Tal representação, no entanto, não caracteriza outros tipos de escrita, denominadas autônomas, por não terem como referência a linguagem articulada para estabelecer a relação entre escrita e mundo (cf. Corrêa, 2013b, p. 67-68). Em segunda instância, conceber a escrita como heterogênea significa não restringi-la à sua condiçẫo de código, mas concebê-la, na diversidade de seus usos e de seus espaços de circulação, como modo de enunciação, em que os sentidos são produzidos por meio de relaçôes simbólicas. A consequência dessa segunda instância é que o sujeito da linguagem aparece ao ser revelado pelas marcas que deixa em seu discurso escrito.

Dessa perspectiva teórica, entendemos a vírgula como um sinal de pontuação que, embora (...) gráfico, é marca linguistica de processos simbólicos que se efetivam na escrita por meio da relação com a oralidade, particularmente por meio do domínio prosódico. Assim, a prosódia é entendida como o eixo linguístico desses processos, os quais são, por sua vez, captados nos textos quando se observa a relação entre: (a) o emprego da vírgula, (b) a organização prosódica marcada pela vírgula e (c) os sentidos produzidos consequentemente por essa organização.

A assunção de uma organização prosódica na língua implica certa posição teórica que concebe a prosódia como parte da estrutura da língua, ou seja, como representável no sistema linguístico. Essa posição é ponto central para a análise do emprego da vírgula e, mais genericamente, para a concepçáo de escrita que assumimos. Ela acarreta considerar que a prosódia integra a língua: a mesma língua que se tem como referencial seja quando se escreve um texto, seja quando se conta uma história numa conversa entre amigos. Em outras palavras, a língua é a mesma no uso da escrita ou da fala, enquanto o que se altera nesses diferentes

A tradição autonomista de estudos da escrita e, consequentemente, dos sinais de pontuação tem seus principais teóricos na escola francesa. Sua principal diretriz consiste em considerar a escrita como um sistema autônomo e com regras próprias que se definem no interior de um espaço gráfico bidimensional e, por isso, a relação com a oralidade é descartada. 
usos da língua são os seus modos de manifestação: gráfico para o caso da escrita e sonoro para o caso da oralidade.

A consideração da prosódia como representável na estrutura da língua é feita segundo a abordagem da fonologia, particularmente segundo os princípios da Fonologia Prosódica, de Nespor e Vogel (1986). Diferentemente dos trabalhos que analisam a prosódia sob o ponto de vista fonético, essa linha pressupóe a existência de uma estrutura abstrata subjacente, responsável pela organização dos sons das línguas que regula a realização fonética de elementos prosódicos. Nesse modelo, tal estrutura é formada hierarquicamente por sete constituintes prosódicos, são eles: sílaba, pé, palavra fonológica, grupo clítico, frase fonológica, frase entoacional e enunciado fonológico ${ }^{2}$.

A formação de cada um desses constituintes obedece a critérios próprios devido à posição de cada um no interior da hierarquia. Por exemplo, para a constituição da palavra prosódica são acionadas informações morfossintáticas, enquanto, para a constituição do sintagma fonológico, informaçóes sintáticas. Para a formação de constituintes mais altos da hierarquia, como a frase entoacional e o enunciado fonológico, são mobilizadas restriçôes de natureza semântico-pragmática. Resulta dessa interface entre informações sintáticas, fonológicas e outras informações gramaticais que os constituintes prosódicos não necessariamente são isomórficos em relação aos constituintes de outros componentes da gramática.

Neste artigo, mobilizamos na análise de vírgulas apenas o constituinte denominado como frase entoacional $(I) .^{3} \mathrm{O}$ algoritmo de formação desse constituinte prevê que as seguintes estruturas sintáticas correspondem a uma I: (i) quaisquer sentenças raiz, (ii) elementos não anexáveis à estrutura da sentença raiz e (iii) elementos remanescentes de uma sentença raiz interrompida por elemento(s) anexado(s) a ela (Nespor e Vogel, 1986, p. 189). Formada a partir dessas bases sintáticas, mas não necessariamente isomórfica a elas, a frase entoacional é a unidade prosódica ao longo da qual se define o contorno da entoação - independente de qual ele seja, por exemplo: no Português Brasileiro, ascendente para perguntas ou descendente para afirmaçóes - e, por isso, seus limites se comportam como as posiçóes na estrutura formal da língua, especificamente em seu eixo sintagmático, onde esses contornos são iniciados ou terminados.

2 Esses constituintes se organizam de acordo com o princípio da Strict Layer Hypothesis, segundo o qual, toda unidade de um dado nível da hierarquia está exaustivamente contida na unidade de nível superior.

3 Encontra-se em Soncin (2014) análise de vírgulas em que os constituintes frase fonológica e enunciado fonológico são mobilizados. 
As fronteiras prosódicas são de fundamental importância na estruturação da língua e, portanto, adquirem relevância teórica tanto para o modelo quanto para a análise do emprego de vírgulas, conforme apresentaremos na seção três. Para a análise do emprego de vírgulas, consideramos, com base em Soncin (2014), que a fronteira prosódica atua como uma estrutura significante que organiza o enunciado escrito privilegiadamente por meio da pontuação em sua significação e em sua constituição formal.

Lembramos que estabelecer relação entre emprego dos sinais de pontuação e prosódia não é proposta nova, ao contrário, ela é constantemente revisitada e suscita polêmicas. Na escola francesa, por exemplo, embora atualmente a tendência à autonomização da escrita seja dominante, a relevância da função prosódica dos sinais de pontuação é abordada nos trabalhos de referência de Damourette (1939) e Catach (1994). No cenário norte-americano, o trabalho de Chafe (1987) se destaca dentre aqueles trabalhos de referência que investiga a relação entre pontuação e prosódia. A partir de experimentos que compararam unidades de pontuação e unidades entoacionais proferidas durante a leitura de textos, o autor avalia que a escrita, apesar de dispor de vários elementos gráficos, não consegue registrar suficientemente as oscilaçóes prosódicas que existem no enunciado falado.

Como Chafe (1987), outros trabalhos comparam unidades de pontuação e realizaçôes prosódicas de leitura ${ }^{4}$. Ao comparar realização gráfica e realização fonética, esse e outros estudos que seguem a mesma abordagem excluem o componente prosódico estruturante da língua que se mantém em ambas as manifestações, oral e escrita. Dessa perspectiva as conclusóes a que chegam se baseiam em índices de suficiência do gráfico em relação ao sonoro: índices de suficiência que podem ser alterados se outra leitura for feita por outro sujeito e produzir outras significaçôes.

Essa, no entanto, não é a abordagem que adotamos, pois não realizamos comparaçóes entre vírgulas empregadas em texto escrito e realizaçóes de fenômenos prosódicos na leitura do mesmo texto. Defendemos que as relaçóes entre o gráfico e o fonético não são, necessariamente, idênticas. Desse modo, nossa análise se baseia na identificação de constituintes prosódicos a partir da identificação da estrutura sintática, com base em algoritmos que estabelecem a interface sintaxe-fonologia, segundo o modelo de Nespor e Vogel (1986). A partir da formação dos constituintes no plano fonológico, identificamos possibilidades de realização fonética para interpretar os textos e os usos de vírgula.

4 Para o Português Brasileiro, estudos com essas características foram feitos por Cagliari (1989) e Pacheco (2003, 2006). 
Esse percurso teórico nos leva a considerar que, ao escrever seu texto, o sujeito mobiliza representação sobre a organização prosódica da língua e sobre o modo como essa organização conduz sentidos nas práticas de oralidade. A representação mobilizada orienta sua produção textual e é marcada na escrita, de modo particular, por meio dos sinais de pontuação. $\mathrm{Na}$ direção contrária, o leitor interpreta as marcas de pontuação por meio do conhecimento linguístico e de (suas) representaçóes sobre o funcionamento prosódico nos textos, podendo atribuir (ou não) a mesma organização prosódica e os mesmos sentidos projetados pelo escrevente, ressignificando o produto escrito.

Portanto, diferentemente das análises que mencionamos, assumimos uma abordagem teórica que nos permite colocar em primeiro plano a consideração do sujeito que escreve e, consequentemente, representações simbólicas desse sujeito acerca do ato de escrever a partir do modo como é guiado pela organização prosódica da língua, integrante de seu conhecimento linguístico.

\section{MATERIAL E METODOLOGIA: OS TEXTOS ESCRITOS POR ESTUDANTES DO ENSINO FUNDAMENTAL}

Os usos de vírgula a serem analisados ocorreram em 284 textos opinativos escritos em contexto escolar por alunos do último ano do Ensino Fundamental, de faixa etária entre 13 e 14 anos. Esse material pertence ao Banco de Dados de Produçóes Escritas do Ensino Fundamental, ${ }^{5}$ disponível gratuitamente em: $<$ http://www.convenios.grupogbd.com/redacoes/Login>.

Os textos utilizados foram produzidos a partir de oficinas de leitura e produção de texto, desenvolvidas numa escola pública situada em zona periférica da cidade de São José do Rio Preto, região noroeste do estado de São Paulo. As oficinas integraram o conjunto de atividades do Projeto de Extensão Universitária "Desenvolvimento de oficinas de leitura, interpretação e produção textual" destinado a alunos das quatro séries/anos do segundo ciclo do Ensino Fundamental. Os textos a partir dos quais fazemos a análise dos usos de vírgula foram produzidos em 2008 em quatro oficinas, sendo que em duas delas foi proposta a produção de

5 O banco de dados conta com duas amostras de textos, uma transversal e outra longitudinal, totalizando 5.284 textos de diferentes gêneros produzidos, entre 2008 e 2011, por 662 alunos de faixa etária entre 10 e 14 anos, pertencentes aos últimos quatros anos do sistema de Ensino Fundamental no Brasil. Foi organizado por meio de financiamentos da Fundação de Apoio à Pesquisa do Estado de São Paulo (Processos: 2013/14546-5 e 2009/14848-6). 
artigo de opiniáo, uma sobre "a internacionalização da Amazônia" e outra sobre "a ação destrutiva do homem no meio ambiente"; em outras duas, foi orientada a produção de carta argumentativa, uma sobre o tema "vantagens e desvantagens de minha escola" e outra sobre "o internetês é ou nâo língua portuguesa?".

$\mathrm{O}$ interesse pelas vírgulas empregadas nesses textos escolares se justifica, em primeiro lugar, pela sua característica principal de deixar visíveis flutuaçóes dos sujeitos escreventes entre o atendimento e o não atendimento às normas de pontuação, tornando visível aos olhos do analista o processo do sujeito escrevente de alçar sua escrita às convençóes apresentadas pela escola. Em segundo lugar, interessa o trabalho com textos dessa natureza, pois torna possível o trabalho com o uso não convencional, ou seja, com o chamado "erro de uso da vírgula", segundo a nomenclatura gramatical.

De nossa perspectiva, o dado não convencional é interessante para análise não só porque, ao estar fora do padrão, dá margem para verificar não coincidências entre o funcionamento linguístico e o funcionamento convencional estabelecido pelas normas (não coincidências que são "camufladas" quando se atende à norma), mas também porque, em geral, são raros os trabalhos sobre pontuação que consideram o uso não convencional de vírgula (ou de qualquer outro sinal de pontuação) como dado de análise. Em geral, esses trabalhos priorizam como material de análise textos de escritores profissionais (como representantes da literatura ou da imprensa), nos quais os empregos da vírgula são prioritariamente convencionais, e discutem as funções linguísticas que esses empregos assumem na escrita segundo um referencial teórico definido. Eventualmente, quando abordam casos em que os sinais de pontuação não são compatíveis com as normas apresentadas pelas gramáticas, esses trabalhos justificam os usos não convencionais como recursos estilísticos usados pelos autores, uma vez que a liberdade ao estilo lhes é permitida justamente por serem escritores profissionais - liberdade não permitida, nem mesmo considerada, na prática escolar para os alunos, uma vez que, na escola, o objetivo das aulas de produção textual é atender à convenção escrita.

Nesta proposta de análise de usos de vírgula em textos escolares, o dado não convencional se configura como lugar que possibilita discutir a complexidade do uso da vírgula como marca gráfica da heterogeneidade da escrita. Ao "estar fora da convenção", o uso não convencional revela um funcionamento linguístico subjacente. Esse olhar téorico-metodológico que atribuímos aos usos não convencionais se fundamenta nas pesquisas pioneiras em aquisição de escrita desenvolvidas no Brasil por Abaurre et al. (1997) que consideram o que está fora das convençôes da escrita como indício valioso da relação do sujeito com a linguagem e - principalmente - nas afirmaçóes de Corrêa (2013a) sobre as marcas do sujeito deixadas 
no fio do discurso. Segundo esse autor, essas marcas remetem a procedimentos de edição ${ }^{6}$ que respondem ao processo histórico de produção dos sentidos e revelam a busca por um sentido pelo sujeito escrevente.

Dada essa perspectiva teórico-metodológica, propomos demonstrar, num primeiro momento, que os usos não convencionais de vírgula não são aleatórios e, ao contrário, se caracterizam por regularidades quanto à organização prosódica que revelam nuances dos processos simbólicos que atuam na escrita, tendo em vista o processo histórico de produção dos sentidos a que respondem. Num segundo momento, em funçáo das regularidades dos usos não convencionais, discutimos os usos convencionais apontando fatores que os aproximam e os distanciam. Portanto, neste trabalho, são analisados usos convencionais e não convencionais da vírgula, com destaque para esses últimos.

Por fim, faz-se necessário explicitar que os usos não convencionais selecionados para análise se referem àqueles em que a vírgula foi empregada no texto e não aos casos em que não foi, embora fosse requerida pela convenção. Esses últimos casos, também usos não convencionais, são definidos pela ausência de emprego da vírgula - e, por isso, náo fazem parte do conjunto de dados analisados.

\section{USOS DE VÍRGULA E ORGANIZAÇÃO PROSÓDICA: RESULTADOS ENCONTRADOS}

Nos 284 textos que compóem o material de análise, encontramos 198 usos não convencionais de vírgula, ou seja, vírgulas que foram empregadas em desacordo com a convenção gramatical. Como já afirmado, esses usos ganham destaque num primeiro momento em nossa análise e, somente após a descrição de suas regularidades de natureza prosódica, discutiremos os usos convencionais de vírgula.

\subsection{Usos não convencionais de vírgula}

6 Por procedimentos de edição, o autor considera, por exemplo, rasuras, alteraçóes de ordem ou mudança de palavras na oração etc. Embora usos não convencionais de vírgula não possam ser considerados segundo a perspectiva da edição por não ser possível garantir que o escrevente retornou ao texto que já escreveu para revisar sua organizaçáo formal e alterá-lo, ancoramo-nos nas ideias do autor - sem responsabilizá-lo pela postura que assumimos - e entendemos que usos não convencionais de vírgula seriam também índices de procedimentos feitos durante a escritura de um texto que respondem ao processo histórico de produção de sentidos. 
No conjunto de 198 usos não convencionais de vírgula, observamos como principal regularidade a relação de identidade entre a posiçâo de emprego da vírgula e a posição de uma fronteira prosódica. Percentualmente, $93,4 \%$ das vírgulas não convencionais foram empregadas em posiçôes onde se reconhecem fronteiras prosódicas. Esse resultado foi comprovado estatisticamente pelo teste não paramétrico Wilcoxon, cujo resultado apontou que as duas variáveis dependentes comparadas - coincidência e não coincidência de usos não convencionais de vírgula e fronteira prosódica - não se relacionam devido ao acaso, evidenciando que a presença de uma fronteira prosódica condiciona de forma praticamente categórica a colocação da vírgula ${ }^{7}$.

No que tange ao tipo de fronteiras prosódicas delimitadas pelos usos não convencionais de vírgula, outra regularidade se apresenta: em 92\% dos casos em que os usos não convencionais de vírgula marcam fronteiras prosódicas, delimitam-se fronteiras de frases entoacionais. Esse resultado permite interpretar que, dentre as unidades prosódicas do modelo de Fonologia Prosódica, a frase entoacional é aquela que organiza estruturalmente o emprego da vírgula, tornando-se a estrutura subjacente à escrita cujas fronteiras se tornam posiçôes potenciais para o emprego de vírgula.

As fronteiras de frases entoacionais delimitadas pelas vírgulas apresentam uma característica que as define: são fronteiras de frases entoacionais não finais, ou seja, marcam o limite entre duas frases entoacionais: o fim de uma e o início de outra. Essa é uma informação importante, pois dialoga com a característica da vírgula de ser empregada apenas entre oraçóes e no interior de orações (Dahlet, 2006). A delimitação por vírgula da fronteira de uma frase entoacional final, ou seja, de uma frase entoacional não seguida por outra, não ocorre nos textos analisados, pois, nesses casos, o sinal de pontuação empregado é o ponto (segundo a orientação convencional) ${ }^{8}$.

Considerando essas regularidades estruturais gerais dos usos não convencionais de vírgula, apresentamos, a seguir, exemplos que ilustram a correspondência entre

7 Nesse teste, a relevância estatística foi observada a partir da obtenção do valor $\mathrm{p}=0,0000$, tendo sido usado o valor de significância $\mathbb{Q}=0,05$.

8 Chamamos a atenção para o fato de que, no último ano do Ensino Fundamental, o índice de emprego de vírgula em posição onde a convenção requer o ponto, em nosso material de análise, é nulo, resultado que se contrapóe a resultados encontrados quando são considerados anos escolares anteriores. Observar o emprego de vírgulas em diferentes anos escolares do Ensino Fundamental é tema de pesquisas desenvolvidas pelo Grupo de Pesquisa "Estudos sobre a linguagem" (CNPq), ao qual pertencemos. 
emprego de vírgula não convencional e fronteira de frase entoacional não final. Destacaremos de que modo a identificação dessa correspondência dá margem para interpretar os significados produzidos dos textos. Iniciemos pelo exemplo 1:

(1) [Acredito que uma pessoa que fica na frente do computador conversando todos os dias,]I [tenha grande dificuldade na hora de produzir um texto,]I [pois saberá diferenciar uma língua da outra.]I

Nessa ocorrência, o uso não convencional de vírgula após a palavra "dias" delimita a fronteira de uma frase entoacional não final que se configura em razão da complexidade sintática do período. Caracterizado sintaticamente por encaixes de orações em uma oração principal, o período conta com oraçóes que dependem estruturalmente uma da outra. Particularmente na posição onde a vírgula não convencional foi empregada, a fronteira de frase entoacional é formada entre sujeito e verbo ([uma pessoa que fica na frente do computador conversando todos os dias $]_{\text {sujeito }}$ [tenha grande dificuldade $[. . .]_{\text {predicado verbal }}$, local em que a vírgula não é permitida pela convenção, pois entre sujeito e verbo há uma relação sintática que não pode ser interrompida por meio da vírgula. No entanto a fronteira prosódica é formada nessa posição, pois uma oração adjetiva está anexada ao sujeito em questão, motivo que, fonologicamente, permite a formação de uma frase entoacional pela possibilidade de realização de um contorno entoacional cujo fim coincide com o fim da oração adjetiva. A formação da frase entoacional se justifica pela necessidade de organizar em porções menores as unidades sintáticas complexas maiores. $\mathrm{Na}$ oralidade, essa fronteira seria reconhecida pela realização de tons de fronteira, ou seja, de tons que caracterizam o fim de um contorno entoacional responsável por sinalizar a segmentação do período. Na escrita, essa fronteira é marcada pela vírgula. Em termos de realização, portanto, a vírgula se encontra na posição onde, pela existência da fronteira prosódica, potencialmente pode ocorrer tom de fronteira com final ascendente, sinalizando a continuaçáo do enunciado, uma vez que não se trata de $I$ final.

Os exemplos (2) e (3) apresentam usos não convencionais de vírgula: em (2), a vírgula é considerada não convencional por estar empregada antes da conjunção aditiva "e" enquanto que, em (3), a vírgula é não convencional por estar empregada entre sujeito e verbo. Assim como no exemplo (1), as vírgulas em (2) e (3) marcam fronteiras de frases entoacionais às quais há a possibilidade de associação de tom de fronteira. Essa estruturação prosódica organiza a segmentação do enunciado e torna mais evidente a organizaçáo semântica dos enunciados. 
(2) [Estou the mandando esta carta,]I [para dizer como é a escola que eu estudo,] I [e dizer qual é as vantagens e desvantagens que existe nela.]I

(3) [Uma das vantagens de estudar nesta escola,]I [é que,]I [com isso]I [conhecemos e criamos muitas amizades]I [e isso aprendemos a nos dar bem com as pessoas de fora.]I

Em (2), a vírgula delimita a fronteira entre duas frases entoacionais e, assim, separa o enunciado em frases entoacionais diferentes, sendo que em cada porçấo segmentada estão explicitadas as duas finalidades apresentadas para o texto ter sido escrito: de um lado, a finalidade de descrever a escola e, por outro, a de avaliar quais são suas vantagens e desvantagens. Embora do ponto de vista sintático que rege a convenção a vírgula seja desnecessária, do ponto de vista prosódico, a vírgula marca a fronteira entre duas frases entoacionais e sinaliza a possível organização do enunciado em duas unidades de entoação. É como se a segmentação prosódica marcada pela vírgula, ao remeter a dois contornos entoacionais - o primeiro levemente ascendente e o segundo descendente - denunciasse o modo como o escrevente constrói sentido por meio da organização que deu ao seu texto: em primeiro lugar, a descrição da escola, em segundo lugar, a avaliação das vantagens e desvantagens.

Em (3), a vírgula delimita, segundo a perspectiva prosódica, a fronteira da primeira frase entoacional do período e também, no domínio semântico, a fronteira entre a apresentação do tópico iniciado naquele parágrafo do texto - as vantagens da escola - e os comentários que se produz sobre esse tópico. Desse modo, a fronteira prosódica delimitada pela vírgula não atua isoladamente, mas organiza a segmentação do texto e, por meio dessa segmentação, os sentidos entre porçóes do enunciado.

Consideremos, por fim, o exemplo $(4)^{9}$ :

(4) [De comer bala, ou chiclete,]I [tudo bem,]I [mas agora o boné,]I [já é demais.] I

9 Para o leitor, faz-se necessário apresentar excerto de texto em que ocorre o exemplo (4): "Venho lhe escrever esta carta para falar sobre as vantagens e as desvantagens dentro da minha escola. / As vantagens que tenho na escola são muitas. / A escola onde eu estudo tem bons: professores, boa disciplina, boa comida, bons eventos, etc. [...] /As desvantagens săo que, na saída do horário da escola, não são muito boas. Tem escola que o sinal bate mais cedo e outras mais tarde, como essa. Outras desvantagens são as normas da escola. Uma delas são, não usar boné./ De comer bala ou chiclete, tudo bem, mas o boné, já é demais." 
$\mathrm{Na}$ ocorrência apresentada em (4), a vírgula não convencional empregada entre o sujeito "boné" e o verbo "e’" marca a fronteira de uma frase entoacional que se forma pela possibilidade de proeminência acentual em "boné". Primeiramente, é importante considerar que o dado (4) ocorreu em uma carta endereçada à professora da turma e teve como tema as vantagens e desvantagens da escola. Os papéis de interlocução definidos para a construção do texto e o fato de o tema confrontar duas perspectivas sobre a escola somados ao modo como as saliências prosódicas funcionam na oralidade nos permitem interpretar que a proeminência prosódica marcada pela vírgula produz o efeito semântico de que a proibição do uso de boné na escola é um exagero.

O tema (vantagens e desvantagens da escola) e o gênero (carta) abriram a possibilidade para a presença de traços linguísticos e discursivos relevantes para a interpretação do uso não convencional de vírgula. $\mathrm{O}$ tema solicitado permite que os estudantes construam enunciados contrastivos em seus textos, enquanto que o gênero permite que o interlocutor seja representado como alguém específico e conhecido (a professora), imprimindo características orais de uma conversação face a face no texto escrito de forma mais marcada do que se faz em outros textos escritos náo argumentativos e de outros gêneros, como um relatório.

Nossa interpretação de que o emprego de vírgula marca foco prosódico é, pois, ancorada na organização do texto e também no modo como as saliências prosódicas funcionam na oralidade. No que diz respeito à organização prosódica, faz-se necessário explicitar que enunciados falados do Português Brasileiro recebem foco prosódico por meio de acento tonal associado à sílaba acentuada da palavra enfatizada seguida de uma (possível) pausa (cf. Fernandes, 2007). No texto em questão, a focalização prosódica (que destaca a palavra "boné" em relação à sequência do enunciado) reforça o efeito semântico-pragmático da proibição de usar boné na escola como um exagero, ao contrapor a informação nova "proibição de uso de boné" à informação já conhecida pelo escrevente "proibição da bala e do chiclete". A focalização contrastiva organiza o sentido do enunciado, uma vez que marca a insatisfação do estudante com a proibição e indica ao leitor o quanto o estudante considera sua escola um espaço conservador: uma desvantagem em seu ponto de vista.

Particularmente, por meio do exemplo (4), procuramos mostrar como uma vírgula, por meio de sua relaçáo com a organização prosódica da língua, pode contribuir para a interpretação dos textos e evidencia a importância da oralidade como parte integrante da construção de sentidos do texto escrito, bem como a atuação do escrevente como sujeito da linguagem. 
De modo geral, por meio da análise dos exemplos selecionados de usos não convencionais de vírgula, procuramos mostrar que: (i) a frase entoacional é uma unidade que proporciona alto poder explicativo para os usos não convencionais da vírgula, pois a percepçáo de sua fronteira condiciona de modo praticamente categórico o emprego de vírgula e (ii) a frase entoacional é relevante tanto para segmentar o enunciado em porçôes, mesmo que essas não correspondam às unidades sintáticas, quanto contribui para a significação do texto.

Vejamos, na próxima seção, exemplos de usos convencionais de vírgula.

\subsection{Usos convencionais de vírgula}

No caso dos usos convencionais de vírgula, as posições em que a vírgula é empregada de acordo com as orientações da convenção gramatical coincidem com fronteiras de frase entoacional em 100\% dos casos analisados, resultado que torna ainda mais robusta a relevância da fronteira de frase entoacional para o emprego da vírgula. Para mostrar a relevância desse resultado, analisamos quatro exemplos. Consideremos primeiramente o exemplo (5).

(5) [A escola onde eu estudo,]I [tem bons professores,]I [boa disciplina,]I [boa comida,]I [bom eventos,]I [etc.]I

As vírgulas destacadas foram empregadas convencionalmente para separar elementos de uma sequência enumerativa. Do ponto de vista prosódico, segundo Nespor e Vogel (1986), em contextos sintáticos de enumeração, cada elemento configura uma frase entoacional própria. Assim, no exemplo (5), os elementos "bons professores", "boa disciplina", "boa comida" e "bom eventos" formam quatro frases entoacionais, fato que define o emprego da vírgula convencional após cada um deles como marca de suas fronteiras. Essa organização em frases entoacionais estrutura a possibilidade de realização de um tom de fronteira levemente ascendente associado à fronteira direita de cada uma das frases entoacionais não finais. Por sua vez, a última frase entoacional da enumeração é, em geral, identificada pelo contorno descendente, à qual é correlacionado não o emprego da vírgula, mas o emprego do ponto. Na oralidade, os sucessivos contornos levemente ascendentes no interior de um enunciado servem náo só para indicar a continuidade do discurso, como também para criar a suspensão do enunciado, sem que este tenha sido concluído.

No exemplo (6), apresentamos um uso de vírgula convencional que separa um elemento adverbial deslocado. 
(6) [Em suma,]I [do que eu escrevi,]I [tem mais desvantagens,]I [do que vantagens.]I

A convenção gramatical do Português Brasileiro orienta que toda expressão adverbial deslocada de sua posição padrão no interior de uma sentença precisa ser acompanhada por vírgulas. No exemplo (6), as vírgulas que delimitam o elemento adverbial "do que eu escrevi" no interior do período atendem ao padrão estabelecido pela convenção. No entanto, as mesmas vírgulas delimitam as fronteiras da frase entoacional formada pela construção adverbial "do que eu escrevi”, pois, segundo o algoritmo de formação de frase entoacional de Nespor e Vogel (1986), todo elemento sintático náo anexável à estrutura da sentença raiz e, por isso, sem lugar fixo na sentença, constitui uma frase entoacional independente.

De formação similar aos adverbiais, as estruturas apositivas, os vocativos e as inserçôes também formam frases entoacionais, uma vez que são, igualmente, estruturas sintáticas não anexáveis à sentença raiz. No exemplo (7), observa-se a delimitação do aposto "brasileiros", feita por vírgulas, que constitui uma frase entoacional.

(7) [O que todos nós,]I [brasileiros,]I [deveríamos fazer é nos juntar]I [e dar um basta]I [e dizer que não queremos o que é nosso, nas mãos de estrangeiros.]I

Segundo a orientação da gramática normativa de Bechara (1999), todo aposto deve ser isolado por vírgulas. Assim, as vírgulas empregadas antes e depois de "brasileiros" em (7) atendem ao padrão sintático esperado pela convenção. Do ponto de vista prosódico, as posiçóes em que as vírgulas se encontram são fronteiras da frase entoacional que se forma a partir da estrutura sintática apositiva. Desse modo, as vírgulas não só delimitam fronteiras sintáticas da estrutura apositiva (a qual se define num nível diferente do nível sintático da sentença raiz), como delimitam também a estrutura prosódica que se forma a partir dessa estrutura apositiva.

Por fim, no exemplo (8), uma vírgula é empregada de acordo com o padrão estabelecido pela convençáo antes de uma oração coordenada iniciada por uma conjunção adversativa.

(8) [Também temos que lembrar,]I [que, a Amazônia concentra uma boa parte de terra aqui,]I [mas não "toda" a parte aqui.]

Segundo as regras de formação da frase entoacional, numa estrutura de coordenação de orações, cada oração coordenada, seja ela justaposta ou ligada à outra por uma conjunçấo, se configura em uma frase entoacional. Desse modo, 
o emprego convencional de vírgulas entre sentenças coordenadas justapostas ou entre sentenças coordenadas ligadas por uma conjunção, como é o caso de (8), em que se tem a vírgula entre duas oraçóes coordenadas ligadas pela conjunção adversativa "mas", caracteriza-se pela delimitação, no plano prosódico, da fronteira prosódica que se encontra entre o fim de uma frase entoacional e o início de outra: em (8), o fim da primeira frase entoacional "a Amazônia concentra uma boa parte de terra aqui" e o início da segunda "mas náo 'toda' a parte aqui", introduzida pela conjunção.

Por meio da análise prosódica desses exemplos, demonstramos que as vírgulas convencionais estão condicionadas a fronteiras de frases entoacionais, assim como as não convencionais analisadas anteriormente. No entanto, como ponto de divergência, enquanto as vírgulas convencionais delimitam unidades prosódicas que são isomórficas em relação às unidades sintáticas, as vírgulas não convencionais delimitam unidades prosódicas não isomórficas em relação à sintaxe, nível da língua que orienta as regras de emprego da pontuação.

\section{IMPLICAÇÓES TEÓRICAS DA RELAÇÃO ENTRE USO DE VÍRGULA E FRONTEIRA PROSÓDICA: DISCUSSÃO DOS RESULTADOS}

A principal conclusão teórica a que chegamos com base nos resultados apresentados diz respeito à consideração de que as vírgulas, empregadas de acordo ou em desacordo com a convenção, marcam posiçóes onde se encontra, subjacente à escrita, uma estrutura prosódica da língua: a da frase entoacional. Desse modo, a descrição prosódica dos usos de vírgula feita na seção anterior não explica o emprego da vírgula por meio da menção direta a uma realização entoacional efetuada pelo escrevente ou por um leitor do texto, mas, diferentemente, é consequência de conceber esse uso como efeito da estruturação fonológica promovida pela frase entoacional. Trata-se de reconhecer, em termos teóricos, que a estrutura se sobrepóe à realização fonética. Ou seja, de reconhecer que as vírgulas não são marcas das realizaçôes fonéticas que ocorreriam caso o texto fosse oralizado; ao contrário, elas marcam a estruturação prosódica da língua (que se dá por meio de frases entoacionais) que compóe a escrita, assim como compóe a oralidade.

Essa conclusão, em termos teóricos, atribui à prosódia um papel integrante no processo de escrita e, particularmente, no ato de pontuar com a vírgula: papel negado tanto pela tradição gramatical quanto por trabalhos de cunho linguístico 
que conferem à prosódia um papel acessório ${ }^{10}$, já que consideram a sintaxe a dimensão linguística que centraliza a organização do emprego da vírgula. Contudo, os resultados que apresentamos mostram que, do ponto de vista do funcionamento linguístico, a dimensão prosódica estrutura os usos de vírgula, tanto os não convencionais quanto os convencionais, o que implica considerar que o domínio de organização desses usos não é exclusividade da sintaxe. De modo particular, as regularidades prosódicas observadas no emprego convencional da vírgula mostram que, diferentemente do que pregam a convenção e os estudos autonomistas, a consideração da prosódia no ato de empregar a vírgula não conduz ao chamado "erro" e, por isso, não pode ser considerada como influência negativa para o ato de empregar vírgulas na escrita, pois, se assim o fosse, a coincidência entre fronteira prosódica e emprego de vírgula não se mostraria em 100\% dos casos de usos convencionais de vírgula e seria observada apenas nos usos não convencionais.

Nesse sentido, nossos resultados corroboram a abordagem teórica de Chacon (1998), para quem os sinais de pontuaçáo delimitam unidades na escrita que se caracterizam pela multidimensionalidade da linguagem, ou seja, delimitam unidades que se definem, ao mesmo tempo, por diferentes dimensóes da linguagem, marcando a atuação da pontuaçẫo em diferentes dimensôes de organização do texto escrito, dentre as quais estâo a dimensão sintática e a dimensão prosódica. Por esse motivo, entendemos com o autor que "nenhum nível da linguagem pode requerer para si o fornecimento exclusivo de normas para o emprego da pontuação" (Chacon, 1998, p. 197).

Nossos resultados ainda apontam para o processo heterogêneo em que a escrita se constitui. Em primeiro lugar, ao argumentarmos que os usos de vírgula se organizam em função da frase entoacional, demonstramos haver estrutura prosódica subjacente à escrita pelo fato de a frase entoacional ser uma estrutura da língua. Em segundo, considerar a presença da estrutura prosódica implica supor que as possibilidades de realização fonética para o padrão definido por essa estrutura encontram-se também subjacentes à escrita - e não fora dela -, mas de modo virtual. Sua realização depende da presença do sujeito escrevente, que, para dar sentido ao enunciado escrito, toma como referência os padróes entoacionais usados na oralidade e, assim, atribui um padrão entoacional à estrutura prosódica presente na escrita em função dos sentidos mobilizados no texto.

10 São os casos tanto da abordagem autonomista quanto dos trabalhos de base fonocentrista que concebem a prosódia segundo suas características fonéticas.

Soncin G.; Tenani, L. Emprego de vírgula e prosódia do Português Brasileiro... 
Defendemos que se trata de um processo em que o aluno enquanto sujeito escrevente organiza prosodicamente sua escrita em função da representação que faz do funcionamento de fenômenos prosódicos na oralidade, como o tom de fronteira, o contorno entoacional focalizador e a pausa. Ou seja, o aluno representa o modo como a realização desses fenômenos produz significados na oralidade, como a criação e a suspensão de expectativas e a produção de elementos focalizados em determinados elementos do enunciado. Desse modo, ao empregar as vírgulas em seu texto, o aluno registra na escrita - não necessariamente de modo consciente o funcionamento da oralidade. Consideramos, portanto, que não se trata de uma escolha pragmática do sujeito de empregar a vírgula com determinada finalidade. Diferentemente, entendemos que o sujeito passa por um processo simbólico que representa as relaçôes entre oralidade e escrita por meio da estruturação prosódica comum a uma e a outra e, assim, não tem necessariamente controle sobre o processo, pois esse último é efeito de sua constituição histórica como sujeito falante e escrevente da língua, sem ser possível que o aluno se desprenda de sua condição de falante quando escreve e de sua condição de escrevente quando fala.

Assim, nossa perspectiva teórica se baseia na tese de Corrêa (2004), que propóe o conceito de heterogeneidade da escrita, de que durante o processo de escrita de um texto, o escrevente constrói imagens sobre seu próprio ato de escrever e produzir sentidos na escrita, levando em consideração os pontos de referência que tem sobre o funcionamento do discurso adquiridos a partir de sua experiência como sujeito da linguagem: um desses pontos de referência é a oralidade, em suas mais diferentes práticas de uso. Dessa maneira, ancorados em Corrêa (2004), interpretamos que a correlação entre vírgula e fronteira de frase entoacional observada nos textos sinalizam momentos em que os sujeitos escreventes, por meio do emprego da vírgula, atualizam sua memória como falantes da língua e fazem representaçóes simbólicas sobre como os fenômenos prosódicos atuam nas diferentes práticas orais e letradas e produzem sentidos. De modo geral, portanto, a análise que apresentamos dos usos de vírgula orientada pela relação intrínseca que esses usos estabelecem com a prosódia impóe assumir a complexidade da atividade de pontuar um texto com a vírgula: complexidade, que se caracteriza, por um lado, pela multidimensionalidade da linguagem, e, por outro, pela heterogeneidade da escrita. 


\section{USOS DE VÍRGULA E REGRAS NORMATIVAS: QUESTÓES DE ORALIDADE E LETRAMENTO EM JOGO?}

A análise dos usos da vírgula mostrou que a prosódia é uma dimensão da linguagem que constitui o emprego da vírgula de modo integrante, uma vez que tanto usos convencionais quanto usos náo convencionais sáo regulados pela estrutura da frase entoacional. No entanto, as normas que estabelecem as convençóes do emprego da vírgula segundo a tradição gramatical são prioritariamente sintáticas e, em geral, desconsideram a atuação da prosódia.

Em contexto escolar, a tradição gramatical é dominante, pois tem a função de promover e difundir o "bom" uso da língua e, consequentemente, o "bom" uso da escrita. Ainda, a prática pedagógica é orientada pela abordagem normativa e, consequentemente, a produção textual dos alunos é avaliada segundo critérios igualmente normativos. Tem-se, pois, que os sinais de pontuação são apresentados segundo suas regularidades sintáticas e a prosódia é apenas um recurso acessório de exemplificações particulares.

Ao ser orientada pela tradição gramatical, a prática de ensino dos sinais de pontuação difunde, assim, um ideal homogêneo de escrita e, por consequência, apaga a complexidade do ato de empregar a vírgula num texto, embora a multidimensionalidade da linguagem e a heterogeneidade da escrita sejam duas características centrais desse sinal de pontuação. Dessa maneira, a observaçáo comparativa entre as normas elencadas e o funcionamento dos usos de vírgula na escrita dos alunos revela a existência de uma lacuna: um espaço entre o ideal homogeneamente sintático presente nas normas e a realidade heterogênea da atividade escrita (constituída estruturalmente pela dimensão prosódica e pelos processos simbólicos que essa dimensão promove na escrita por meio de sua funçáo na oralidade).

Para superar essa lacuna (uma das fontes de problemas para o ensino de língua portuguesa), propomos que, ao contrário das ideias que norteiam o modelo vigente de ensino da pontuação, o caráter heterogêneo dos sinais de pontuação seja explorado. Ou seja, apagar as regularidades prosódicas do uso da vírgula não contribui para a compreensão sobre a natureza heterogênea do ato de empregar as vírgulas na escrita. Isto posto, propomos que a prática didática considere a prosódia, ao lado da sintaxe, como parte estruturante do processo de pontuar com vírgulas um texto. Nessa proposta, o professor proporciona o desenvolvimento da reflexão dos estudantes sobre os usos da vírgula em seus textos. De modo amplo, 
o professor deverá ter em seu horizonte que o emprego da vírgula, tanto o não convencional quanto o convencional,

delimita unidades prosódicas que compóem significativa e formalmente a escrita, com a diferença de que os usos não convencionais são identificados mais por seu caráter icônico para compor os significados enquanto que os usos convencionais são identificados mais por seu caráter formal de organização da escrita. (Soncin, 2014, p. 150)

Considerando os usos de vírgula por meio da abordagem proposta, o professor no Ensino Fundamental tem condiçóes de avaliar em que medida os processos de representação da oralidade constituem os textos dos alunos: ora mais por uma relação de crença na identidade entre oral e escrito, marcada predominantemente pelos empregos não convencionais que produzem significados nos textos ao iconizarem uma possibilidade de realização fonética, ora mais por uma relação de padronização da estrutura linguística comum à escrita e à oralidade, marcada predominantemente pelo uso de vírgula convencional, já que, ao corresponder às unidades sintáticas convencionais, as unidades prosódicas delimitadas pelas vírgulas registram a formalidade esperada pela escrita convencional, considerada na avaliação do letramento do escrevente. Essa tensão a que o aluno está sujeito enquanto aprendiz foi discutida quando da análise dos usos convencionais e náo convencionais da vírgula.

\section{REFERÊNCIAS}

Abaurre, MBM. Fiad, RS. Mayrink-Sabinson, MLT. Cenas de aquisição da escrita: o sujeito e o trabalho com o texto. Campinas: Mercado de Letras/ALB; 1997.

Anis J. Pour une graphématique autonome. Langue française. Paris; 1983, 59: 31-44.

Bechara E. Moderna Gramática Portuguesa. Rio de Janeiro: Lucerna; 1999.

Cagliari LC. Marcadores prosódicos na escrita. Estudos linguísticos. XVIII Anais de Seminários do GEL. Lorena; 1989, 195-203.

Catach N. La Ponctuation. Paris: Presses Universitaires de France; 1994.

Chacon L. Ritmo da escrita: uma organizaçâo do heterogêneo da linguagem. São Paulo: Martins Fontes; 1998. 
Chafe W. Punctuation and the prosody of written language (Technical Report n. 11). Berkeley: Center for the study of writing; 1987.

Corrêa MLG. O modo heterogêneo de constituição da escrita. São Paulo: Martins Fontes; 2004.

Corrêa MLG. Bases teóricas para o ensino da escrita. Linguagem em (Dis)curso. Tubarão; 2013a, 13 (3): 481-513.

Corrêa MLG. Heterogeneidade da escrita no ensino: das modalidades às relaçôes intergenéricas. In: Pereira LA, Cardoso I, (coord.). Reflexão sobre a escrita: o ensino de diferentes géneros de textos. Aveiro: UA Editora/Universidade de Aveiro; 2013b. p. 67-91.

Dahlet V. As (man)obras da pontuação: usos e significaçôes. São Paulo: Associação Editorial Humanitas; 2006.

Damourette J. Traité moderne de ponctuation. Paris: Larousse; 1939.

Fernandes FR. Ordem, focalização e preenchimento em português: sintaxe e prosódia [tese]. Campinas: Instituto de Estudos da linguagem, Universidade Estadual de Campinas; 2007.

Nespor M, Vogel I. Prosodic Phonology. Dordrecht: Foris Publications; 1986.

Pacheco V. Investigação fonético-acústico-perceptual dos sinais de pontuação enquanto marcadores prosódicos [dissertação]. Campinas: Instituto de Estudos da Linguagem, Universidade Estadual de Campinas; 2003.

Pacheco $\mathrm{V}$. O efeito dos estímulos auditivo e visual na percepção dos marcadores prosódicos lexicais e gráficos usados na escrita do português brasileiro [tese]. Campinas: Instituto de Estudos da Linguagem, Universidade Estadual de Campinas; 2003.

Soncin, GCN. Língua, discurso e prosódia: investigar o uso da vírgula é restrito? Vírgula! [tese]. São José do Rio Preto: Instituto de Biociências, Letras e Ciências Exatas, Universidade Estadual Paulista; 2014.

Recebido em: 28/07/2015

Aceito em: 04/11/2015

Soncin G.; Tenani, L. Emprego de vírgula e prosódia do Português Brasileiro... 